\title{
Recovery Dynamics in Invertebrate Communities Following Water-Quality Improvement: Taxonomy- Vs Trait-Based Assessment
}

Author(s): Evelyne Arce, Virginie Archaimbault, Cédric P. Mondy and Philippe Usseglio-Polatera Source: Freshwater Science, 33(4):1060-1073. 2014.

Published By: The Society for Freshwater Science

URL: http://www.bioone.org/doi/full/10.1086/678673

BioOne (www.bioone.org) is a nonprofit, online aggregation of core research in the biological, ecological, and environmental sciences. BioOne provides a sustainable online platform for over 170 journals and books published by nonprofit societies, associations, museums, institutions, and presses.

Your use of this PDF, the BioOne Web site, and all posted and associated content indicates your acceptance of BioOne's Terms of Use, available at www.bioone.org/page/terms of use.

Usage of BioOne content is strictly limited to personal, educational, and non-commercial use. Commercial inquiries or rights and permissions requests should be directed to the individual publisher as copyright holder. 


\title{
Recovery dynamics in invertebrate communities following water-quality improvement: taxonomy- vs trait-based assessment
}

\author{
Evelyne Arce ${ }^{1,2,5}$, Virginie Archaimbault ${ }^{3,6}$, Cédric P. Mondy ${ }^{4,7}$, and Philippe Usseglio-Polatera ${ }^{2,8}$ \\ ${ }^{1}$ IRSTEA, UR MALY, 5 rue de la Doua - CS 70077, F-69626 Villeurbanne, France \\ ${ }^{2}$ Université de Lorraine, LIEC, CNRS UMR 7360, F-57070 Metz, France \\ ${ }^{3}$ IRSTEA, UR HBAN, F-92761 Antony, France \\ ${ }^{4}$ EAWAG, Swiss Federal Institute of Aquatic Science and Technology, CH-8600 Dübendorf, Switzerland
}

\begin{abstract}
Sewage effluents are recognized as one of the most common sources of river degradation. However, very few investigators have tried to evaluate ecosystem recovery after cessation of wastewater treatment plant (WWTP) discharge. Our goals were to: 1) analyze invertebrate community responses to chemical water quality and habitat changes after wastewater treatment improvement, and 2) evaluate the abilities of taxonomy-based and trait-based approaches to detect and explain community recovery processes in a multistressor context. We studied the benthic macroinvertebrate community of 3 sites of a heavily impaired stream (the Vistre River, France) during a 4-y period that included the decommissioning of a deficient WWTP (WWTP-A) and the commissioning of a new one (WWTP-B). We assessed the recovery of the benthic community by comparing observed taxonomic and trait-based (i.e., functional) metrics at the study site to values estimated with information from least-impaired reaches of the same river type. Most taxonomy-based characteristics of benthic communities subjected to WWTP-A recovered in 3 mo, but the recovery time of several trait-based characteristics was $\sim 2 \mathrm{y}$. No change was observed in taxonomic and trait-based diversity during the 4-y study. Taxonomy-based metrics detected the first signs of river reach recovery rapidly, but combinations of trait-based metrics and taxonomic abundance-based metrics are more likely to identify functional recovery of invertebrate assemblages faced with water-quality improvement, even when multiple stressors impaired upstream reaches.
\end{abstract}

Key words: pollution abatement, macroinvertebrates, taxonomic metrics, trait-based approach, null model, wastewater treatment plant

Sewage effluents are among the most common sources of river degradation (Paul and Meyer 2001) and can lead to multistressor impacts, including organic matter (OM) and nutrient inputs. In most industrialized countries, wastewater treatment practices have been developed to limit stream pollution. Nevertheless, numerous studies have revealed a strong impact of wastewater treatment plant (WWTP) discharge on invertebrate communities. The decrease in $\mathrm{O}_{2}$ concentration and the increase in conductivity, suspended solids, and nutrient concentrations in rivers receiving WWTP effluents (Gower and Buckland 1978, Daniel et al. 2002, Canobbio et al. 2009) lead to a decline in invertebrate richness (Kondratieff and Simmons 1982), mainly because of a decrease in the richness of the most sensitive aquatic insect orders (e.g., Ephemeroptera, Plecoptera, and Trichoptera [EPT]; Ortiz and Puig 2007, Pinto et al. 2010). In contrast, the abundance of tolerant taxa, such as Oligochaeta and Chironomidae, increases globally (Campbell 1978, Whitehurst and Lindsey 1990, Rueda et al. 2002).

The Water Framework Directive (WFD; European Commission 2000) has required achievement of a good ecological and chemical status for all surface water bodies in the European Union by 2027. Reducing chemical pressures from WWTPs is a possible approach for improving the ecological quality of many streams (Carey and Migliaccio 2009). Authors of several studies have concluded that implementing secondary or tertiary treatment of wastewaters in WWTP improves the physicochemical quality of the receiving streams (Daniel et al. 2002, Mladenov et al. 2005, Gücker et al. 2006). However, studies of biotic responses to water-quality improvement are rare (e.g., Crawford et al. 1992, Besley and Chessman 2008), and because very few

E-mail addresses: ${ }^{5}$ evelyne.arce@univ-lorraine.fr; ${ }^{6}$ virginie.archaimbault@irstea.fr; ${ }^{7}$ cedric.mondy@eawag.ch; ${ }^{8}$ philippe.usseglio-polatera@univ-lorraine.fr

DOI: 10.1086/678673. Received 08 August 2013; Accepted 12 March 2014; Published online 19 September 2014.

Freshwater Science. 2014. 33(4):1060 1073. @ 2014 by The Society for Freshwater Science. 
of them have been based on functional metrics (Spänhoff et al. 2007), mechanistic responses driving community recovery are poorly known.

Taxonomy-based metrics, such as taxonomic richness and diversity, or biotic indices based on taxon sensitivity to pollution (e.g., the Average Score Per Taxon [ASPT] in the UK; Armitage et al. 1983), have been used widely for evaluating the quality of freshwater ecosystems via macrobenthic communities (Bonada et al. 2006). Generalization of these indices to all types of streams has been difficult because of natural differences in taxonomic groups caused by differences in regional conditions (Lenat 1993, Usseglio-Polatera et al. 2000b), so new bioassessment approaches, based on theoretical concepts in ecology (Southwood 1977, 1988, Townsend 1989), were developed.

The trait-based approach is focused on well defined, measurable properties of organisms that influence their fitness (McGill et al. 2006, Violle et al. 2007) and ecosystem functioning (Tilman 2001). In a given habitat templet (e.g., the River Habitat Templet; Townsend and Hildrew 1994), species are likely to be selected on the basis of the efficiency of their trait combinations in particular environmental conditions (Townsend et al. 1997). Thus, functional trait-based metrics have the potential to elucidate the ecological mechanisms structuring macroinvertebrate communities more directly than taxonomy-based metrics (Townsend and Hildrew 1994, Statzner and Bêche 2010). Trait-based approaches have been used to assess various anthropogenic pressures on streams and rivers, including WWTP effluents (Charvet et al. 1998, Lecerf et al. 2006), sediment toxicity (Archaimbault et al. 2010), and multiple stressor gradients (Dolédec et al. 1999, Usseglio-Polatera and Beisel 2002, Gayraud et al. 2003, Mondy and Usseglio-Polatera 2013; see also the review by Menezes et al. 2010). In a recent comparative study, Marzin et al. (2012) suggested that functional trait-based metrics might discriminate anthropogenic disturbances better than taxonomy-based metrics, but very few investigators have used a functional trait-based approach to examine invertebrate community recovery after disturbance cessation (Rabeni et al. 1985, MacLeod et al. 2008).

Our goals were to: 1 ) analyze invertebrate community responses to chemical water quality and habitat changes after wastewater treatment improvement, and 2) evaluate the abilities of taxonomy- and functional trait-based approaches to detect and explain community recovery processes in a multistressor context. We hypothesized that modifications in wastewater treatment would rapidly improve water quality and create favorable ecological niches for more pollution-sensitive taxa. Based on published literature on the effects of organic enrichment and WWTP effluents on benthic macroinvertebrates, we hypothesized the response patterns of a set of taxonomy- and trait-based metrics (Tables 1, 2). We hypothesized that taxonomybased metrics (e.g., the number of taxa in different faunal groups, such as EPT) might respond quickly to waterquality improvement because of rapid recolonization of restored stream sections by individuals from adjacent unimpaired reaches or neighboring (near-)pristine streams. We

Table 1. Taxonomic metrics that have been used to assess invertebrate community responses to waste water treatment plant (WWTP) pollution. $\uparrow=$ increase, $\downarrow=$ decrease in metric value. n.o. $=$ not observed.

\begin{tabular}{|c|c|c|c|c|c|}
\hline Metric & Label & Definition (references) & $\begin{array}{l}\text { Already observed responses } \\
\text { to WWTP inputs (references) }\end{array}$ & $\begin{array}{l}\text { Expected } \\
\text { responses } \\
\text { to improved } \\
\text { water chemistry }\end{array}$ & $\begin{array}{l}\text { Observed results } \\
\text { at restored sites }\end{array}$ \\
\hline $\begin{array}{l}\text { Taxonomic } \\
\text { richness }\end{array}$ & $\mathrm{S}$ & Total number of taxa & $\begin{array}{l}\downarrow \text { (Kondratieff and Simmons } \\
\text { 1982, Prenda and Gallardo } \\
\text { Mayenco 1996, Rueda et al. } \\
\text { 2002, Canobbio et al. 2009) }\end{array}$ & $\uparrow$ & $\uparrow$ \\
\hline $\begin{array}{l}\text { \% } \mathrm{EPT} \\
\text { richness and } \\
\text { abundance }\end{array}$ & $\begin{array}{l}\mathrm{EPT}(\mathrm{S}) \% \text { and } \\
\mathrm{EPT}(\mathrm{Q}) \%\end{array}$ & $\begin{array}{l}\text { \% Ephemeroptera, } \\
\text { Plecoptera and Trichoptera } \\
\text { in total richness (S) and } \\
\text { total abundance (Q) } \\
\text { (Lenat 1993) }\end{array}$ & $\begin{array}{l}\downarrow \text { for both EPT richness (Ortiz } \\
\text { and Puig 2007, Pinto et al. 2010) } \\
\text { and abundance (Pinto et al. 2010) }\end{array}$ & $\uparrow$ & $\begin{array}{l}\uparrow \mathrm{EPT}(\mathrm{S}) \% \\
\text { n.o. } \mathrm{EPT}(\mathrm{Q}) \%\end{array}$ \\
\hline $\begin{array}{l}\% \text { GOLD } \\
\text { richness and } \\
\text { abundance }\end{array}$ & $\begin{array}{l}\text { GOLD }(S) \% \text { and } \\
\operatorname{GOLD}(\mathrm{Q}) \%\end{array}$ & $\begin{array}{l}\text { \% Gastropoda, Oligochaeta } \\
\text { and Diptera in total } \\
\text { richness }(\mathrm{S}) \text { and total } \\
\text { abundance }(\mathrm{Q}) \\
\text { (Pinto et al. 2004) }\end{array}$ & $\begin{array}{l}\uparrow \text { for both GOLD richness } \\
\text { and abundance (Pinto et al. 2004) }\end{array}$ & $\downarrow$ & n.o. \\
\hline $\begin{array}{l}\text { Shannon } \\
\text { diversity }\end{array}$ & $\mathrm{H}^{\prime}$ & $\begin{array}{l}\sum\left(\left[p_{i}\right] \log _{2}\left[p_{i}\right]\right), \text { where } \\
p_{i}=\text { proportion of taxon } \\
i \text { in the assemblage (Shannon } \\
\text { and Weaver 1949) }\end{array}$ & $\begin{array}{l}\downarrow \text { (Kondratieff and Simmons } \\
\text { 1982, Prenda and Gallardo } \\
\text { Mayenco 1996, Rueda et al. 2002, } \\
\text { Canobbio et al. 2009) }\end{array}$ & $\uparrow$ & n.o. \\
\hline
\end{tabular}


Table 2. Biological trait categories and functional (trait) diversity indices that have been used to assess invertebrate community response to waste water treatment plant (WWTP) pollution. The full description of trait categories is given in Table S3. $\uparrow=$ increase, $\downarrow=$ decrease in metric value. n.o. $=$ not observed, $\mathrm{OM}=$ organic matter, $\mathrm{DO}=$ dissolved $\mathrm{O}_{2}, \mathrm{FPOM}=$ fine particulate organic matter, IS = intermediate site.

\begin{tabular}{|c|c|c|c|c|c|}
\hline Trait & Categories & $\begin{array}{l}\text { Previously observed } \\
\text { responses to WWTP } \\
\text { inputs (references) }\end{array}$ & $\begin{array}{l}\text { Expected response } \\
\text { to improved water } \\
\text { chemistry }\end{array}$ & $\begin{array}{l}\text { Hypothesized mechanism } \\
\text { for recovery }\end{array}$ & $\begin{array}{l}\text { Observed results } \\
\text { at restored sites }\end{array}$ \\
\hline $\begin{array}{l}\text { Maximum } \\
\text { size }\end{array}$ & $\geq 2 \mathrm{~cm}$ & $\uparrow($ Charvet et al. 1998) & $\downarrow$ & $\begin{array}{l}\text { Lower assimilation efficiency } \\
\text { of large organisms leads to } \\
\text { higher mortality in habitats } \\
\text { with lower OM inputs }\end{array}$ & $\downarrow$ \\
\hline $\begin{array}{l}\text { Life cycle } \\
\text { duration }\end{array}$ & $\geq 1 \mathrm{y}$ & & $\uparrow$ & $\begin{array}{l}\text { Reduced need for resilience } \\
\text { capacity }\end{array}$ & $\downarrow$ \\
\hline Voltinism & Polyvoltine & $\begin{array}{r}\uparrow(\text { Charvet et al. 2000, } \\
\text { Marzin et al. 2012) }\end{array}$ & $\downarrow$ & $\begin{array}{l}\text { Reproduction more likely } \\
\text { to succeed }\end{array}$ & $\downarrow$ \\
\hline \multirow[t]{2}{*}{ Reproduction } & Ovoviviparity & $\uparrow($ Marzin et al. 2012) & $\downarrow$ & Reduced need to protect eggs & $\downarrow$ \\
\hline & Asexual & & $\downarrow$ & $\begin{array}{l}\text { Reduced need for resilience } \\
\text { capacity }\end{array}$ & $\downarrow$ (observed at IS) \\
\hline Dispersal & Aquatic passive & & $\downarrow$ & Reduced need to avoid stressor & n.o. \\
\hline \multirow[t]{2}{*}{ Resistance } & Eggs, statoblasts & & $\downarrow$ & Reduced need to resist stressor & $\uparrow$ \\
\hline & None & & $\uparrow$ & & $\downarrow$ \\
\hline \multirow[t]{2}{*}{ Respiration } & Tegument & $\uparrow($ Charvet et al. 1998) & $\downarrow$ & $\begin{array}{l}\text { Response to higher DO } \\
\text { (lower stream productivity) }\end{array}$ & n.o. \\
\hline & Aerial & & $\uparrow$ & & $\begin{array}{l}\uparrow \text { (observed for } \\
\text { the category } \\
\text { 'spiracle') }\end{array}$ \\
\hline \multirow{3}{*}{$\begin{array}{l}\text { Locomotion/ } \\
\text { relation to } \\
\text { substrate }\end{array}$} & Crawlers & $\uparrow($ Charvet et al. 1998) & $\downarrow$ & & $\uparrow$ \\
\hline & Interstitial & & & & $\downarrow$ \\
\hline & Attached & & $\uparrow$ & $\begin{array}{l}\text { Less clogging, more substrate } \\
\text { available for attachment }\end{array}$ & $\uparrow$ \\
\hline \multirow[t]{2}{*}{ Food } & $\begin{array}{l}\text { FPOM/ } \\
\text { microorganisms }\end{array}$ & & $\downarrow$ & $\begin{array}{l}\text { Decrease in FPOM provided } \\
\text { by WWTP input }\end{array}$ & $\downarrow$ \\
\hline & $\begin{array}{l}\text { Living } \\
\text { microphytes }\end{array}$ & & $\uparrow$ & $\begin{array}{l}\text { Less suspended FPOM leads } \\
\text { to higher water transparency, } \\
\text { less substrate clogging, and } \\
\text { faster biofilm development }\end{array}$ & $\uparrow$ \\
\hline \multirow[t]{4}{*}{$\begin{array}{l}\text { Feeding } \\
\text { habits }\end{array}$} & $\begin{array}{l}\text { Deposit and } \\
\text { filter feeders }\end{array}$ & $\begin{array}{l}\uparrow \text { (Hynes 1960, Kondratieff } \\
\text { and Simmons 1982, } \\
\text { Shieh et al. 1999, } \\
\text { Marzin et al. 2012) }\end{array}$ & $\downarrow$ & $\begin{array}{l}\text { Reduced FPOM availability } \\
\text { leads to lower relative } \\
\text { abundance of FPOM feeders }\end{array}$ & $\begin{array}{l}\downarrow \text { (observed for } \\
\text { deposit feeders) } \\
\uparrow \text { (observed for } \\
\quad \text { filter feeders) }\end{array}$ \\
\hline & Piercer & $\uparrow($ Charvet et al. 1998) & $\downarrow$ & $\begin{array}{l}\text { Less filamentous algae } \\
\text { because of decreased } \\
\text { eutrophication }\end{array}$ & $\downarrow$ \\
\hline & Scrapers & $\begin{array}{l}\downarrow \text { (Shieh et al 1999, } \\
\quad \text { Kerans and Karr 1994) }\end{array}$ & $\uparrow$ & $\begin{array}{l}\text { More biofilm development } \\
\text { should lead to higher } \\
\text { relative abundance } \\
\text { of taxa feeding on it }\end{array}$ & $\uparrow$ \\
\hline & Predators & & & & n.o. \\
\hline $\begin{array}{l}\text { Biological/ } \\
\text { ecological } \\
\text { diversity }\end{array}$ & & $\downarrow$ (Lecerf et al. 2006) & $\uparrow$ & $\begin{array}{l}\text { Increasing habitat diversity } \\
\text { and stability leads to more } \\
\text { diverse ecological niches }\end{array}$ & n.o. \\
\hline
\end{tabular}


also hypothesized that abundance-based taxonomic metrics (e.g., diversity indices) or trait-based metrics (e.g., observed biological attribute frequencies) of communities in restored reaches might be slower to respond because change in these metrics would require within-reach settlement of more colonists from each affected taxon. We also predicted that trait-based metrics would provide more information than taxonomy-based metrics on the functional processes occurring during the recovery period.

\section{METHODS}

\section{Study sites}

Our study was done on the Vistre River (southern France; Fig. 1A). Stream discharge is influenced by the high seasonal variation in precipitation that characterizes the Mediterranean climate and varies from $0.57 \mathrm{~m}^{3} / \mathrm{s}$ during the dry season (May-October) to $23.00 \mathrm{~m}^{3} / \mathrm{s}$ during the wet season (November-April) (annual mean $=2.12 \mathrm{~m}^{3} / \mathrm{s}$ ). The watersheds of the Vistre River and its tributaries are highly modified by human land uses (63\% agricultural and 18\% urban land use; Corine Land Cover 2006) and the river and its tributaries have been subjected to domestic, industrial, and agricultural effluents that added $1240 \mathrm{t}$ of $\mathrm{N}$ and $226 \mathrm{t}$ of P/y in the early 2000s (RMC Water Agency 2000). To limit P and N inputs from the main city in the watershed (Nîmes; Fig. 1B), a new WWTP (WWTP-B; capacity $=230,000$ population equivalents $[\mathrm{PE}]$, mean discharge $=0.32 \mathrm{~m}^{3} / \mathrm{s}$ ), equipped with improved biological treatment capable of reducing $\mathrm{N}, \mathrm{P}$, and $C$ inputs, was put into service in June 2008. WWTP-B replaced an older WWTP (WWTP-A; capacity = 130,000 $\mathrm{PE}$, mean discharge $=0.10 \mathrm{~m}^{3} / \mathrm{s}$ ) that discharged effluents into a small tributary of the Vistre River, $\sim 1.5 \mathrm{~km}$ upstream of the confluence of WWTP-B effluents with the Vistre River (Fig. 1C).

We selected 3 study sites on a 3-km-long river section in the vicinity of the WWTP-A and WWTP-B effluent inputs. The upstream site (US) is upstream of the confluence of the Vistre River and its tributary that received WWTP-A effluents. US is a water-quality control site for the study reach. The intermediate site (IS) was $\sim 1 \mathrm{~km}$ downstream of WWTP-A input into the Vistre River (until its decommissioning in June 2008) and is upstream of the WWTP-B inputs. The downstream site (DS) was influenced successively by WWTP-A and WWTP-B inputs before and after June 2008, respectively (Fig. 1C).

\section{Least-impaired river reaches}

All along its course, the Vistre River is subjected to strong anthropogenic pressures. Seven WWTPs, with a

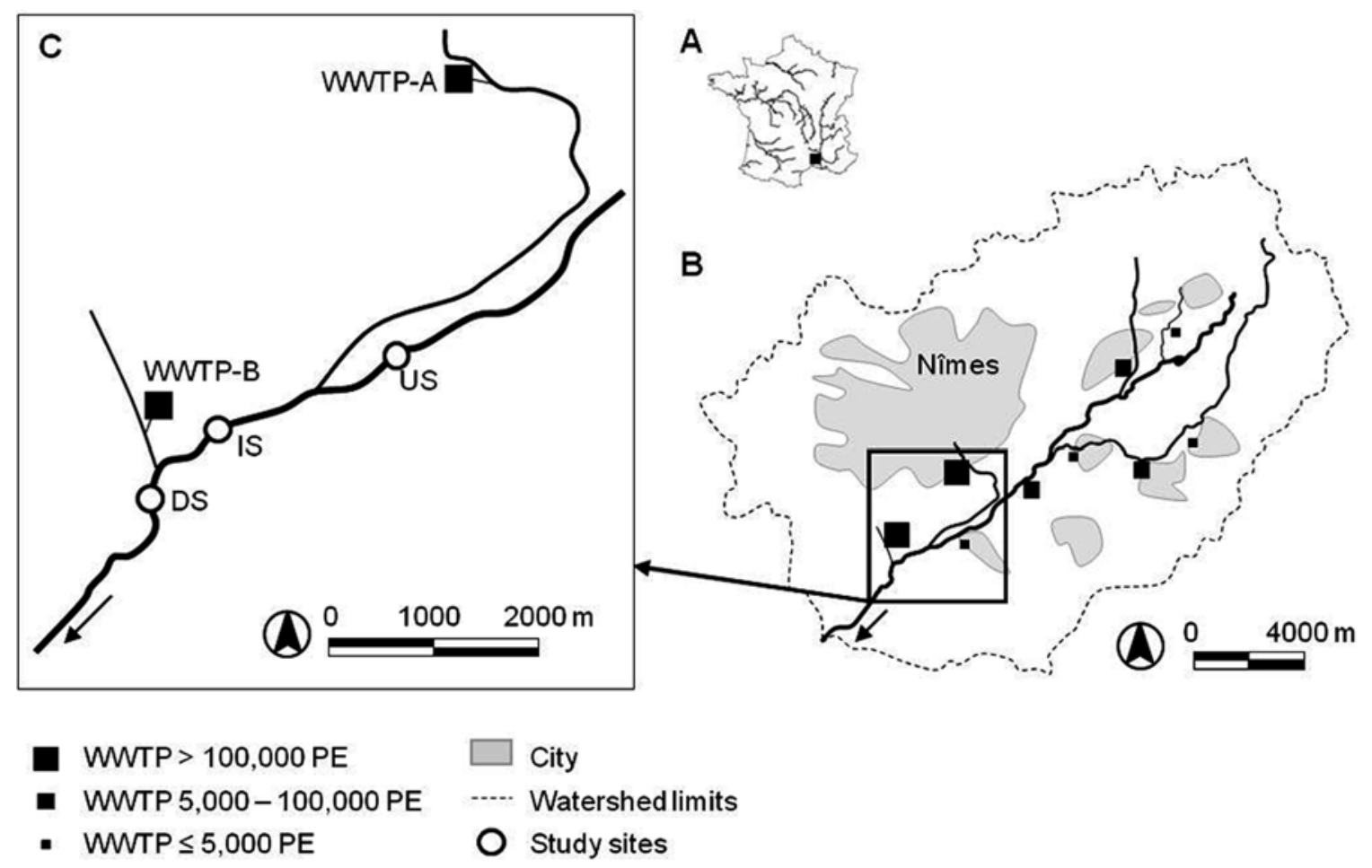

Figure 1. Map of the Vistre River basin and study sites. A. Location of the Vistre River basin in France. B. Vistre River watershed showing the study reach and locations and capacities of wastewater treatment plants (WWTPs). C. Locations of the 3 study sites and WWTP A and B sewage inputs. US = upstream site, IS = intermediate site, DS = downstream site, PE = population equivalent. 
total capacity of 50,000 PE, discharge effluents in the river or its tributaries upstream of the study reach (Fig. 1B). Therefore, no site with chemical characteristics close to the reference conditions is available in the Vistre River watershed. Moreover, the Vistre River has a long history of channelization that has strongly modified its bed (e.g., creation of the Vistre canal during the $17^{\text {th }}$ century and important riverbed straightening along the main part of its longitudinal profile during the $20^{\text {th }}$ century; RMC Water Agency 2000). Thus, US is a control site that enables us to discuss benthic community recovery resulting from waterquality improvement at IS and DS relative to the physicochemical and hydromorphological constraints already impairing the study reach.

To evaluate the ecological recovery of the 3 study sites on a global (not only relative) basis, we compared the characteristics of local benthic assemblages to those of assemblages from least-impaired river reaches (LIRRs; Statzner et al. 2005) of the same stream type (i.e., MP6 type [small-medium Mediterranean streams]; see Wasson et al. 2002 for a detailed description of the typology of French streams). We extracted these data from national survey databases (Mondy et al. 2012, Mondy and UsseglioPolatera 2013). Potential LIRRs have been characterized using a quality index, bounded by 0 and 100 and divided into 5 quality classes $(0-20=$ bad, $20-40=$ poor, $40-60=$ moderate, $60-80=$ good, $80-100=$ high quality), and calculated for each of 10 water-quality and 7 habitatdegradation pressure categories (described by Mondy et al. 2012, following Oudin and Maupas 2003). A given reach is considered an LIRR if it meets the following criteria: 1) no pressure category with a quality index $<40,2$ ) environmental information available for $\geq 2 / 3$ of the 17 predefined pressure categories, and 3) mean quality index over the available pressure categories $>60$. We selected 7 LIRRs, each sampled 1 to 4 times between 2006 and 2010 (i.e., 15 sampling events). The 7 LIRRs, US, IS, and DS were sampled according to the French normalized sampling protocol for wadeable rivers (Norm AFNOR XP T 90-333; AFNOR 2009b). Chemical-quality data for LIRRs are given in Table S1.

\section{Field and laboratory designs}

At US, IS, and DS, we measured dissolved $\mathrm{O}_{2}$ (DO) with a field probe (OXY 330; WTW, Weilheim, Germany). We collected water samples in autumn before (September 2006, October 2006, September 2007) and after (September 2008, 2009, 2010) WWTP-A was decommissioned, transported them to the laboratory, and stored them at $4^{\circ} \mathrm{C}$. We measured $\mathrm{NO}_{2}{ }^{-}, \mathrm{PO}_{4}{ }^{3-}$, and total $\mathrm{P}\left(\mathrm{P}_{\text {tot }}\right)$ by spectroscopy according to French standard protocols [NFT 90-015-2 (AFNOR 2010a); NF EN 26777 (AFNOR 1993); NF EN ISO 6878 (AFNOR 2005), respectively] and $\mathrm{NO}_{3}{ }^{-}$by ion chromatography [NF EN ISO 10304 (AFNOR 2009a)].
We collected benthic macroinvertebrates in September in 2007, 2008, 2009, and 2010 (1 time before and 3 times after WWTP-A was decommissioned) with the multihabitat sampling protocol applied at LIRRs (AFNOR 2009b). We collected 12 sample units per site from predefined substrate types with a Surber sampler (area $=0.05 \mathrm{~m}^{2}$, mesh size $=500 \mu \mathrm{m})$ and pooled them to yield site samples with homogeneous sampling effort (see Mondy et al. 2012 for further details). We preserved pooled samples in $4 \%$ formalin in the field and transferred them to the laboratory where they were sieved. We sorted and identified all invertebrates to the level defined by the French normalized protocol (Norm AFNOR XP T 90-388; AFNOR 2010b); i.e., genus for mollusks, crustaceans, and insects (except Diptera and some subfamilies of Coleoptera, Trichoptera, and Heteroptera); family for planarians, leeches, and dipterans; and higher identification level for other taxonomic groups (Oligochaeta). We counted all individuals.

\section{Data analyses}

We ran a normalized Principal Component Analysis (nPCA) on $\mathrm{NO}_{2}{ }^{-}, \mathrm{NO}_{3}{ }^{-}, \mathrm{P}_{\text {tot }}, \mathrm{PO}_{4}{ }^{3-}$, and DO concentrations to illustrate major differences in water chemistry among study sites and sampling events (Table S2). We projected LIRRs on the $1^{\text {st }}$ factorial plane as supplementary individuals (i.e., samples were not used to construct the factorial axis). We used the ade4 library (Chessel et al. 2004) in R (version 3.0.0; R Project for Statistical Computing, Vienna, Austria) to run the nPCA.

We used both taxonomic and functional approaches to describe spatiotemporal changes in the Vistre River community. We selected 30 taxonomic metrics, including total richness, taxonomic diversity, and the proportions of major taxonomic groups in terms of richness and abundance (Table S3). We made community response predictions for 6 of the metrics that have been useful for studying invertebrate community response to WWTP pollution (reviewed in Table 1 ). We removed rare taxa (taxa with only 1 occurrence and $<5$ individuals during the whole sampling program) from the analysis. We based the functional approach on 51 trait-based metrics, including the proportional representation of 47 categories from 11 biological traits and 4 trait-based diversity and evenness metrics (Tables S4, S5).

We resolved biological traits in different semiquantitative (e.g., maximal potential size) or qualitative (e.g., respiration) categories. We fuzzy-coded preferences of taxa by assigning to each taxon a score describing its affinity to each trait category (see Chevenet et al. 1994 for further details), from 0 indicating no affinity to 3 or 5 (according to the trait complexity and the global amount of available autecological information) indicating high affinity (Tachet et al. 2010). For each taxon $\times$ trait, we transformed affinity scores into a relative-use frequency distribution (Eq. 1). We calculated the proportional representation of trait cat- 
egories in each invertebrate assemblage by averaging the taxon frequency distribution weighted by the log of their respective abundances (Eq. 2; see Archaimbault et al. 2005 for further details).

$$
\begin{gathered}
F_{i, T, c}=\frac{A_{i, T, c}}{\sum_{j}^{n} A_{i, T, c}} \\
F_{c o m m, T, c}=\frac{\sum_{i}^{N}\left(F_{i, T, c} \log \left(Q_{i}+1\right)\right)}{\sum_{i}^{N} \log \left(Q_{i}+1\right)}
\end{gathered}
$$

where for a given trait $T$ and a given trait-category $c, F_{i, T, c}$ is the relative use frequency of category $j$ by taxon $i, A_{i, T, c}$ is the fuzzy-coded affinity score, $F_{\text {comm }, T, c}$ is the proportional representation of the same trait category in the community, $Q_{i}$ is the abundance of the taxon $i, n$ is the number of categories of the trait $T$, and $N$ is the number of taxa in the community.

We calculated trait-based diversity and evenness by applying the Shannon (Shannon and Weaver 1949) and Pielou (Pielou 1966) index formulae, respectively, to the relative distribution of individuals among functional groups of invertebrates exhibiting homogeneous combinations of biological or ecological attributes (Usseglio-Polatera et al. 2000a). We also calculated the average score per taxon (ASPT), which is a measure of the mean pollution sensitivity of site invertebrate assemblages (Armitage et al. 1983), and the proportional representation of 6 trait categories describing the preferences of taxa along an increasing gradient of organic contamination (= saprobity; Sládeček 1973) and habitat eutrophication (Table S6).

\section{Null model applied on least-impaired river reaches}

We applied null models to LIRR faunal data to eliminate individual LIRR-specific particularities and to estimate metric values that potentially could be observed in least-impaired conditions corresponding to the river type including the Vistre River. We applied a 2-step algorithm based on taxon abundances to generate 1000 randomly assembled community matrices from the LIRR data matrix (15 LIRR samples $\times 113$ taxa). A detailed description of the selected randomization procedure is available in supplementary material (Appendix S1). For each expected matrix including 15 random assemblages, we calculated the taxonomic and functional metrics and generated a final null distribution of 15,000 values for each metric. This distribution was used to assess the deviation of observed assemblages from estimated LIRR conditions. The intervals including $99 \%$ of the simulated LIRR values for a given metric are shown in Figs $2 \mathrm{~A}-\mathrm{J}$ and $3 \mathrm{~A}-\mathrm{L}$. The probability that observed values outside this interval actually belong to the reference-value distribution will be $<1 \%$. Each individual metric has the potential to indicate if the test site must be assigned to LIRR or a degraded status. Community recovery was considered as attained for a given metric if its value moved from outside to inside the 99\% interval of LIRR values during the 3-y period after WWTP-A cessation. We used the vegan library (Oksanen et al. 2013) to run the randomization procedure in $\mathrm{R}$.

\section{RESULTS \\ Chemical characteristics}

The first 2 factorial axes (F1, F2) of the nPCA explained 52.9 (F1) and $26.6 \%$ (F2) of the total variance, respectively (Fig. 4A, B). F1 was strongly and negatively correlated with $\mathrm{P}_{\text {tot }}, \mathrm{PO}_{4}{ }^{3-}$, and $\mathrm{NO}_{2}{ }^{-}$(Fig. $4 \mathrm{~A}$ ) and described an increase in nutrient enrichment from the positive to the negative ends of F1. All LIRR samples, projected on the $1^{\text {st }}$ factorial plane as supplementary individuals, were at the extreme positive side of F1. US samples also were at the positive side of F1, except in 2007 (Fig. 4B). This axis explains betweenyear variation in IS and DS water-chemical composition related to changes in wastewater treatment. Before 2008, both IS and DS were on the negative side of F1. After September 2008, all water samples (at any site) shifted toward the positive side of F1. This change highlighted a decrease in most measured nutrient concentrations and an increase in DO. F2 mainly showed higher $\mathrm{NO}_{3}{ }^{-}$concentrations in DS than in IS before WWTP-A was decommissioned.

\section{Taxonomic approach}

Between-site and between-year variations in taxonomic metrics are shown in Table S3. Those providing the clearest information on invertebrate recovery are illustrated in Fig. 2A-J. Taxonomic metrics exhibited various temporal profiles, even at US where only 9 metrics provided values in the LIRR distribution during the whole study period ( $\mathrm{Ta}$ ble S3). Five metrics never reached the range of values associated with the LIRR distribution. Richness-based metrics (Fig. 2A, C-F), and in particular, metrics for most pollutionsensitive insect orders (e.g., EPT and Odonata), were quite stable and within or very close to the range of LIRR values during the 4-y study period, whereas abundance-based metrics were more variable (Fig. $2 \mathrm{G}-\mathrm{J}$ ).

Before WWTP-A was decommissioned, taxonomic richness at IS and DS (10 and 14, respectively) were lower than their respective LIRR values, whereas taxonomic richness at US (39) was within the range expected at LIRRs (Fig. 2A). Just 3 mo after WWTP-A was decommissioned (2008), total richness had increased at both IS and DS. At IS, total richness did not differ from values expected at LIRR sites (Fig. 2A). At US, taxonomic diversity was always lower than expected in LIRRs and decreased during the study period (Fig. 2B), whereas IS and DS showed a weak increase in diversity, which was always lower than LIRR values (Fig. 2B).

In 2007 (i.e., before the implementation of WWTP-B), Trichoptera were not found at IS or DS (Fig. 2C, G), and 

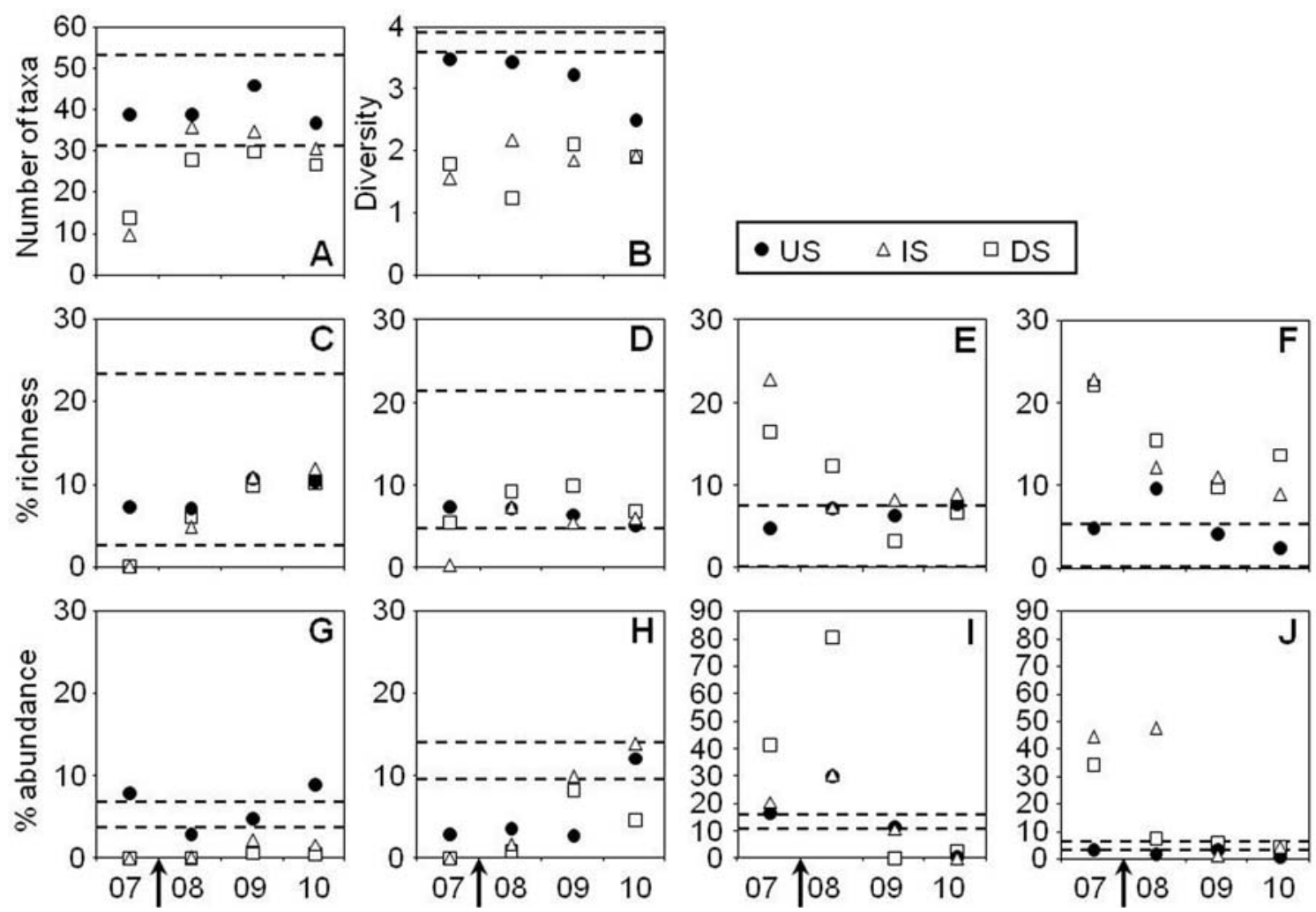

Figure 2. Total richness (A), taxonomic diversity (B), \%Trichoptera richness (C), \% Ephemeroptera richness (D), \% Crustacea richness (E), \% Hirudinea richness (F), \% Trichoptera abundance (G), \% Ephemeroptera abundance (H), \% Crustacea abundance (I), and \% Oligochaeta abundance (J) at the 3 study sites during the 4 y study. Dotted lines show the limits of the confidence interval including 99\% of the least impaired river reach values derived from the null model approach. Arrows show when WWTP A was decommissioned and WWTP B was commissioned. Numbers on $x$ axis are years (2007 2010). See Fig. 2 caption for further details.

Ephemeroptera were not found at IS (Fig. 2D, H). During the same period, mayflies contributed $<1 \%$ to total abundance at DS (Fig. 2H). From 2008-2010, the proportions of Trichoptera and Ephemeroptera taxa at IS and DS were similar to LIRR values (Fig. 2C, D). However, the increase in Trichoptera relative abundance at IS and DS was quite limited during the study period and did not reach LIRR values (Fig. 2G). The relative abundance of Ephemeroptera increased at both IS and DS in 2009, and attained the range of values expected in LIRRs at IS in the 2009 and 2010 surveys (Fig. 2H).

In 2007, Crustacea and Hirudinea at IS and DS had higher relative richness (17-23\%) than expected at LIRRs (Fig. 2E, F). The relative richness in Crustacea decreased to the LIRR range at IS in 2009 and at DS in 2010 (Fig. 2E). The relative richness of Hirudinea decreased at IS and DS after WWTP-A was decommissioned, but never attained LIRR range (Fig. 2F). Crustacea and Oligochaeta were the 2 most abundant groups in the Vistre River benthic community (Fig. 2I, J). Crustacea relative abundance increased strongly at DS in 2008, but decreased drastically in 2009 and 2010 at both IS and DS and reached values lower than expected in LIRRs (Fig. 2I). At IS and DS in 2007,
Oligochaeta relative abundances were 7 and 6 times higher, respectively, than the upper limit of LIRR values (Fig. 2J). In 2008 at DS and 2009 at IS, the relative abundance of Oligochaeta decreased until it was close to the upper limit of LIRR values (Fig. 2J).

\section{Functional approach}

We selected 10 categories from 5 relevant traits to describe community recovery (Table 2 ) and to discuss potential changes in macrobenthic community functioning during the study period (Fig. 3A-J). Temporal changes in the 6 other traits were less clear (Table S5) and are not presented in Fig. 3.

The proportions of most selected trait categories at US were close to those expected in LIRRs (Fig. 3A-J), except that the proportion of filter-feeders was higher than LIRR values throughout the 4-y study (Fig. 3C). In 2008, benthic assemblages at US had lower proportions of scrapers and deposit feeders (Fig. 3A, B) and a higher proportion of large organisms $(>2 \mathrm{~cm}$ ) (Fig. 3F) than expected at LIRRs. In 2010, the proportions of small and multivoltine organisms at US were higher than expected at LIRRs (Fig. 3E, H). 

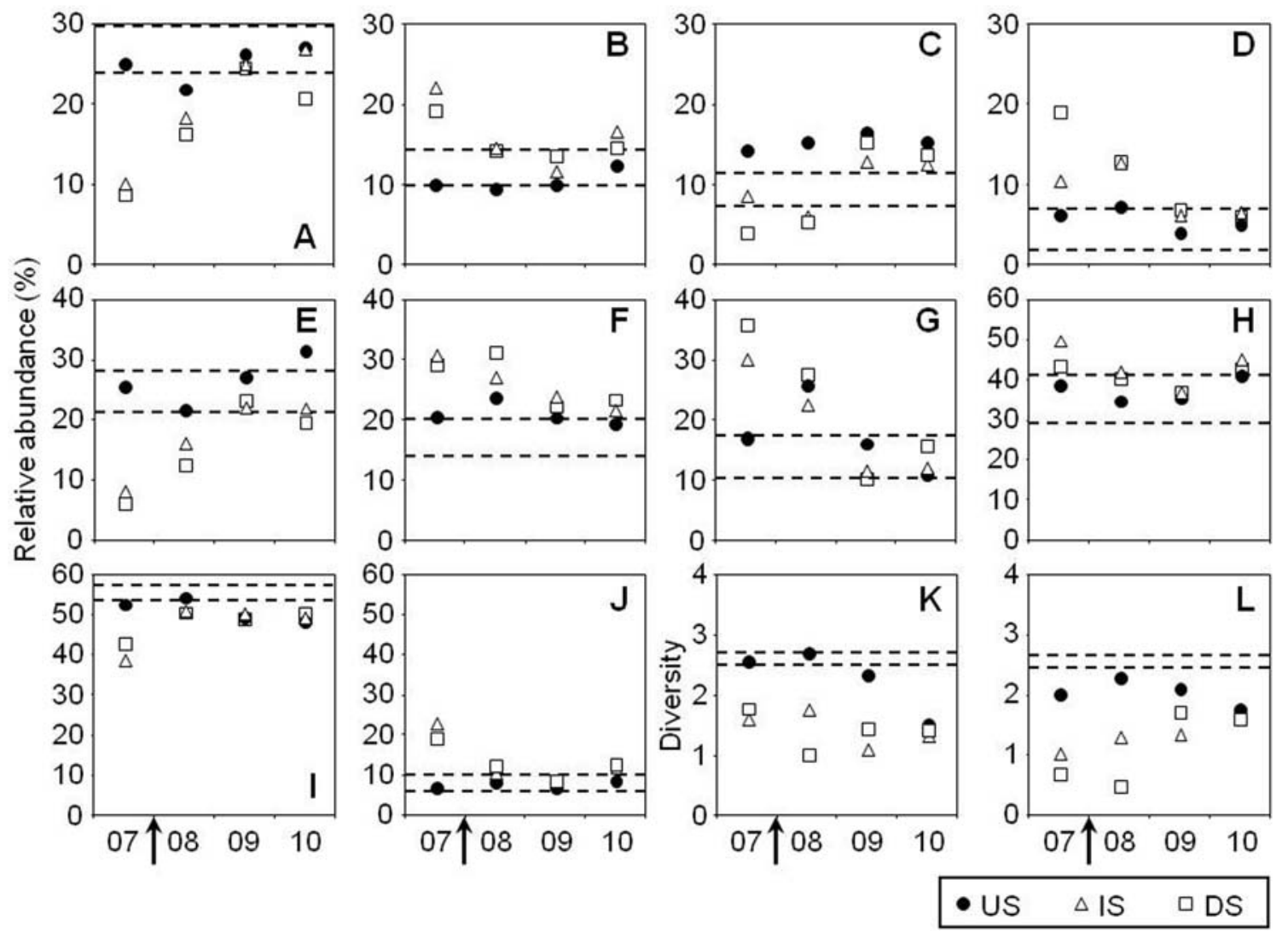

Figure 3. Relative abundances of scrapers (A), deposit feeders (B), filter feeders (C), piercers (D), organisms with maximum size $\leq 0.5 \mathrm{~cm}(\mathrm{E})$, organisms with maximum size $\geq 2 \mathrm{~cm}(\mathrm{~F})$, ovoviviparous organisms $(\mathrm{G})$, polyvoltine organisms $(\mathrm{H})$, crawlers $(\mathrm{I})$, organisms living in substrate interstices (J), and biological trait based (K) and ecological trait based (L) diversity.

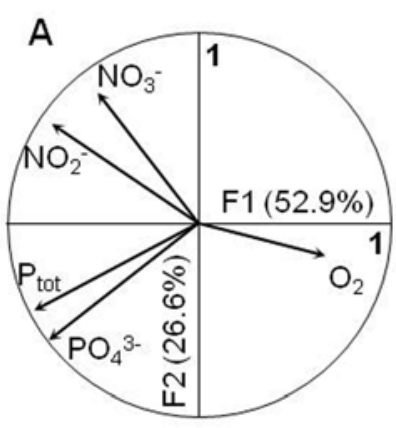

- Before WWTP cessation - After WWTP cessation

- Upstream site $\Delta$ Intermediate site

- Downstream site x Least impaired river reaches

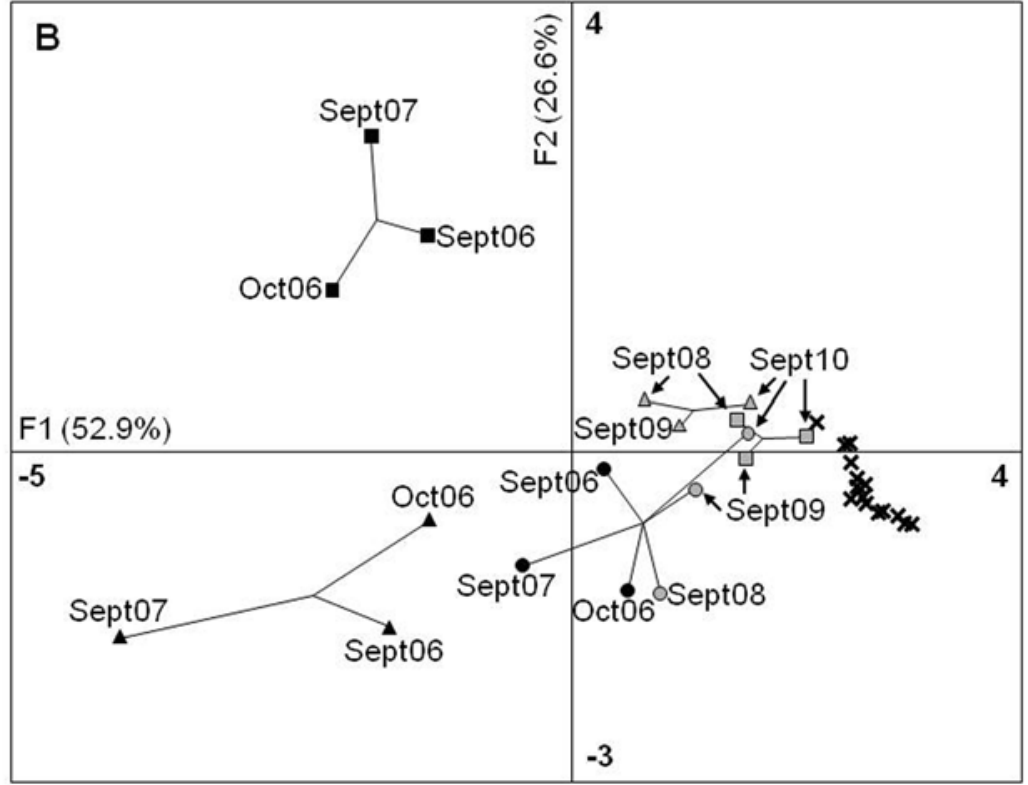

Figure 4. Normalized principal component analysis (nPCA) on the chemistry data $(18$ [site $\times$ date] $\times 5$ variables) showing correla tions of the chemical variables with the first 2 factors (A) and locations of the samples on the $1^{\text {st }}$ factorial plane (B). Samples were grouped by site and date (before [2006 2007] and after [2008 2010] WWTP A was decommissioned). See text for details regarding least impaired river reaches. $P_{\text {tot }}=$ total $P$. 
In 2007, IS and DS benthic assemblages had lower proportions of scrapers, small organisms, and crawlers (Fig. 3A, E, I) and a higher proportion of deposit feeders, piercers, and large, ovoviviparous or multivoltine organisms, living in substrate interstices (Fig. 3B, D, F-H, J) than expected at LIRRs.

Major changes in proportions of trait categories in benthic assemblages at IS and DS occurred between 2007 and 2009, and more trait categories had proportional representation expected at LIRRs in 2009 than in 2007. The proportion of scrapers and small organisms increased strongly in 2008 and reached the LIRR range in 2009 at both sites (Fig. 3A, E). In contrast, the proportion of deposit feeders, piercers, and ovoviviparous, multivoltine, or interstitial organisms decreased (Fig. 3B, D, G, H, J). The decreasing proportion of large organisms (by $\sim 10 \%$ ) and the increasing proportion of crawlers were not sufficient to allow metrics for IS and DS assemblages to reach the LIRR range (Fig. 3F, I). Most changes in proportions of trait categories at IS and DS that occurred in 2008-2009 persisted in 2010.

\section{DISCUSSION}

\section{Water-quality recovery}

Before 2008, WWTP-A severely impaired the quality of the Vistre River at IS and DS by discharging high amounts of $\mathrm{P}$ and $\mathrm{N}$ and inducing severe $\mathrm{O}_{2}$ depletion. Decommissioning WWTP-A significantly improved water quality at both sites, and the effluents from WWTP-B did not alter this recovery in water-quality. Based on the French system of water-quality classification (SEQ-eau; Oudin and Maupas 2003), $\mathrm{NO}_{2}{ }^{-}$and $\mathrm{NO}_{3}{ }^{-}$concentrations at IS and DS, shifted from bad and poor quality, respectively, before 2008, to good and moderate quality after WWTP-A was decommissioned. $\mathrm{P}_{\text {tot }}$ concentration was reduced enough to reach good quality at both sites in 2009 and 2010. As hypothesized, the chemical recovery of water quality after WWTP-A was decommissioned happened very quickly. Water quality at both sites reached that of US in $<3$ mo and came closer to LIRR condition.

\section{Recovery target}

Agriculture and urbanization have long-term, nearly constant effects (e.g., diffuse inputs of nutrients and pesticides from agricultural soil after field application) on the Vistre River. The US site had poorer water quality than LIRRs (e.g., less positive F1 coordinates than LIRRs in the PCA; Fig. 4B). Several taxonomy- (e.g., proportion of EPT richness) and trait-based (e.g., proportions of shredders, filter-feeders, and predators; Table S5) metrics at US never matched the range of LIRR values. Moreover, lower taxonomic and ecological trait diversity than expected in LIRRs for all study sites indicates that larger-scale anthropogenic filters were still acting on the benthic assem- blages of the entire study reach. The ASPT index and the saprobity and river trophic status profiles of invertebrate communities confirm a high degree of organic or nutrient contamination, even at US (Table S6). The Vistre River also has a long history of channelization, which has decreased habitat stability (e.g., by increasing flood stress; Wyzga 1996, Negishi et al. 2002) and diversity (Boon 1988). The simultaneous effects of constant chemical pressure and channelization could delay settlement of species normally expected in this stream type, e.g., Plecoptera species of the genera Nemoura, Protonemura, Leuctra, Perla, and Siphonoperla, which are absent in US but present in LIRRs.

In this multistressor context, the null-model approach, which puts the recovery process of IS and DS faunal assemblages into perspective, has enabled evaluation of the constraints on invertebrate recovery imposed by factors other than the WWTP-A and its decommissioning. This approach enabled us to evaluate the recovery of benthic biota by comparing the observed assemblages to both the control assemblage (local scale) and the expected assemblage (global scale). The $1^{\text {st }}$ biotic recovery target could be considered as attained if the proportion of diagnostic metrics providing values in the range of LIRR values (for the corresponding stream type) at the test site were close to the proportion at the control site. Application of this approach to the 2010 results indicated that biotic recovery at IS (40.0 and $31.4 \%$ of taxonomy- and trait-based metric values in the LIRR range, respectively) and DS (36.7 and $25.5 \%$, respectively) was not complete 3 y after WWTP-A was decommissioned (Fig. 5). The proportions of metrics in the LIRR range was much lower at IS and DS than at US (60.0 and $39.2 \%$, respectively). The $2^{\text {nd }}$ recovery target could be considered attained at the watershed scale (i.e., taking into account all of the anthropogenic pressures from the upper reaches potentially impairing the study reach), if a minimal predefined proportion of metric values in the test site were in the range of LIRR values. This predefined proportion should depend on the selected percentage of simulated values included in the LIRR range (i.e., 99\% of the simulated LIRR values in Figs 2, 3), the objective of the study, and the environmental context (e.g., the intensity of anthropogenic pressures at the watershed scale). Selecting a high percentage (e.g., 99 or 95\%) when defining the LIRR distribution will minimize the risk of Type 1 (inferring impairment when it does not exist) statistical error, but will increase the risk of Type 2 (not detecting impairment when it does exist) error. Selecting a lower percentage (e.g., 50 or $70 \%$ ) will minimize the risk of Type 2 error, but will increase the risk of Type 1 error. The $1^{\text {st }}$ strategy combined with a rather low requested percentage of observed metric values in the LIRR range could be applied when anthropogenic constraints at the watershed scale are high (e.g., to detect the $1^{\text {st }}$ signs of reach restoration in globally adverse environmental conditions more easily). The $2^{\text {nd }}$ strategy combined with 


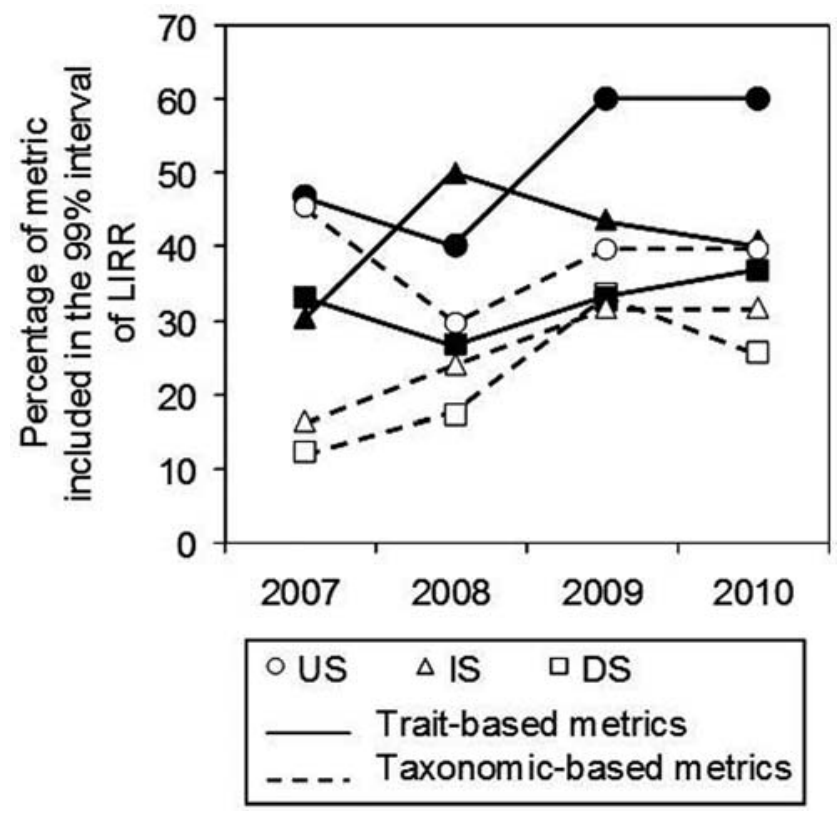

Figure 5. Percentages of taxonomy based and trait based metric values in the $99 \%$ confidence interval of least impaired river reaches (LIRRs) at the upstream (US), intermediate (IS), and downstream sites (DS) during 20072010.

a rather high requested percentage of observed metric values in the LIRR range should be more appropriate in ecosystems with high ecological value or specific conservation objectives.

\section{Evaluating recovery using taxonomic metrics}

Only 3 mo after WWTP-A was decommissioned (September 2008), several Ephemeroptera and Trichoptera genera (Baetis, Cloeon, Caenis, Hydropsyche, and Hydroptila) had recolonized IS and DS (Fig. 2C, D). Corresponding taxonomy-based metrics responded quickly to habitat restoration as hypothesized. The recovery of the macroinvertebrate community composition in the Vistre River was more rapid than the recovery described by Besley and Chessman (2008). They observed complete recovery of macroinvertebrate community composition $>1$ y after a WWTP was decommissioned even though water-chemistry recovered in only 1 mo. Between-study differences in invertebrate recovery measured with metrics of taxonomic occurrence will depend on the distance of potential sources of colonists (Downes et al. 2002), the colonization abilities of taxa, and the environmental quality of the habitat between the sources of colonists and the study site. For example, Hydropsyche and Baetis imagines recolonizing downstream reaches after 3 mo are strong fliers and can lay eggs or clutches rapidly in restored areas during the breeding season (Collier and Smith 1998). In the Vistre River, sources of potential colonists are close to the impaired sites (e.g., US is $\sim 2 \mathrm{~km}$ upstream of IS) and no migration barrier limits invertebrate drift
(Crawford et al. 1992). This proximity probably allowed rapid recolonization by amphibiotic insects (Fig. 2C, D). However, in a multistressor context, decommissioning WWTP-A was not sufficient to attain Ephemeroptera and Trichoptera abundances expected in LIRRs during the study. General degradation of streams in the watershed (by physical alterations and water contamination) probably has reduced the availability of habitats in the benthic mosaic suitable for the more stenotopic species (e.g., Plecoptera larvae) in the areas adjacent to the study site. Combined with poor aerial dispersal capacity of adults (Usseglio-Polatera and Tachet 1994, Briers et al. 2002, Macneale et al. 2005), these unfavorable conditions are likely to limit stonefly settlement strongly. As expected, most taxon abundance-based metrics (e.g., diversity indices) recovered slower than occurrencebased metrics.

\section{Evaluating recovery using trait-based metrics}

Many investigators have demonstrated that functional traits can indicate effects of environmental disturbance (Dolédec et al. 1999, Archaimbault et al. 2010, Mondy et al. 2012) or discriminate among types of impairment (Dolédec and Statzner 2008, Townsend et al. 2008, Wooster et al. 2012, Mondy and Usseglio-Polatera 2013). Most traits that responded to improved water-quality after WWTP-A was decommissioned followed predictions (Table 2). In particular, feeding habit preferences (Hynes 1960, Kondratieff and Simmons 1982, Kerans and Karr 1994, Marzin et al. 2012), maximal potential size (Charvet et al. 1998), reproduction (e.g., reproduction strategy, Marzin et al. 2012; voltinism, Charvet et al. 2000), and relationships with substrate (Charvet et al. 1998) behaved as expected. Most of the observed trait-based responses to water-quality improvement could be related to: 1) decreased intensity of anthropogenic (mainly chemical) pressure, 2) adjustment of assemblages to new habitat conditions, or 3) adjustment of site assemblages to new trophic resources. Some traits related to resilience (e.g., polyvoltinism, Fig. $3 \mathrm{H}$; asexual reproduction) and resistance (e.g., ovoviviparity and ability to move in bottom substrate interstices; Fig. 3G, J, respectively) may become less advantageous when temporal heterogeneity (Townsend and Hildrew 1994) and stressor intensity decrease. The decrease in substrate clogging resulting from a decline in FPOM inputs could have led to an increase in available clean bottom surfaces that would benefit attached organisms (Table S5) and crawlers (Fig. 3I). Decreasing in-stream suspended particulate material probably led to reduced food availability for deposit feeders (Fig. 3B) and favored scrapers eating benthic biofilm (Fig. 3A). Reduced OM inputs also could have led to an increase in small organisms in benthic assemblages at both IS and DS (Fig. 3E).

In contrast, a few trait-based metrics did not match predictions. For example, the relative abundance of poly- 
voltine organisms increased in IS and DS assemblages in 2010. However, this increase was limited (8.4 and 5.9\%, respectively) and also occurred at US (5.6\%), possibly indicating an increase in disturbance in 2010, e.g., more variable hydrological regime or water chemistry during a period of invertebrate community response to environmental characteristics (e.g., estimated at $\sim 4$ mo by Floury et al. 2013) relative to the 2 previous years. Moreover, the proportion of filter-feeders consequent to declining suspended particulate material did not decrease as expected in IS and DS after WWTP-A was decommissioned (Fig. 3C). However, this proportion was always lower at IS and DS than at US, a result indicating that factors external to WWTP-A (e.g., planktonic resources from upstream reaches, bottom substrate quality) also were affecting filter-feeder abundances in IS and DS.

\section{Different recovery times for different types of metrics}

The perceived time needed for recovery by benthic communities can differ strongly depending on the set of descriptors examined. Several taxon occurrence-based metrics (e.g., taxonomic richness, Trichoptera or Ephemeroptera richness) indicated recovery of invertebrate assemblages to the US level within 3 mo. In contrast, many metrics based on biological traits recovered to the US level after 1 or $2 \mathrm{y}$ (Table S3). Taxonomic and functional diversity and evenness did not recover within the 3 y after WWTP-A was decommissioned (Figs. 2B, 3K, L).

New taxa were found during 2008-2010 at both IS and DS. These new taxa are the reason for the rapid recovery of taxon occurrence-based metrics. However, the number of taxa with a relative abundance $>5 \%$ did not increase. Despite the shift in taxonomic community composition resulting from water-quality improvement, IS and DS invertebrate communities remained dominated by a small number of taxa. Three taxa before and 4 taxa after WWTP-A was decommissioned contributed 95 and $82 \%$ of the total abundance, respectively. Recovery of a stable and diverse invertebrate assemblage seems to be a long-term process that could be constrained by habitat instability in the Vistre River. If improved water-quality conditions allowed recolonization by sensitive taxa, these individuals probably had to compete intensively with the more tolerant, well established taxa that still dominate IS and DS benthic assemblages. Thus, rapid recolonization of sites by some pollution-sensitive Ephemeroptera and Trichoptera individuals does not reflect complete and stable recovery of the whole assemblage.

Considering only one aspect of benthic community attributes (i.e., taxonomic composition, trait combinations, or taxonomic/functional diversity) or preselecting a given time-scale for the biotic survey of restoration measures can introduce serious bias in the evaluation of the efficacy of a restoration action (e.g., pollution abatement). In the
Vistre River, as hypothesized, taxon occurrence-based metrics seemed to respond faster than trait-based metrics to chemical improvement. These metrics can be used to survey the early response of invertebrate assemblages after restoration actions, but this early response does not imply a complete biotic recovery. Thus, taxonomic abundancebased metrics and trait-based metrics should be included systematically in the ecological diagnosis of mitigation of anthropogenic pressure because they are more reliable than taxonomic occurrence-based metrics for examining critical long-term mechanisms governing successful habitat restoration and for demonstrating complete functional recovery of local assemblages.

\section{Conclusion}

Our study highlighted the positive effect of improving the quality of wastewater effluents on the invertebrate communities of the receiving stream. However, when the stream is subjected to multiple stressors at the catchment scale, oneoff management actions to improve local water quality do not allow the complete return of reach communities to LIRR condition. We recommend definition of 2 bioticrecovery targets. The $1^{\text {st }}$ target could be intended to evaluate the relative efficacy of local restoration measures for improving habitat condition at the reach scale. The $2^{\text {nd }}$, more ambitious target should be to evaluate the river recovery at global (e.g., watershed) scale. If WWTP standardization is an important action to improve the composition, structure, and functions of invertebrate assemblages, then restoration of hydromorphological characteristics of streams, including habitat structure, flow regime, and hydrological connectivity at large spatial scale also should be considered to provide complete recovery of local assemblages in multistressed reaches.

\section{ACKNOWLEDGEMENTS}

This study was supported by the Agence de l'Eau Rhône Méditerranée \& Corse, the Syndicat Mixte du Bassin versant du Vistre, and Cemagref/IRSTEA. Chemical analyses were per formed by the Freshwater Chemistry Laboratory (IRSTEA). We are especially grateful to Marie Claude Roger, Guillaume Le Goff, Aurélie Josset, Heliott Touron Poncet, Yolande Gautier, Chloé Louche, and Julio Arce Funck for their help during the field and laboratory work. The authors are very grateful to Editor Pamela Silver, Associate Editor Bruce Chessman, and 2 anony mous referees for valuable comments and suggestions that have helped improve this manuscript.

\section{LITERATURE CITED}

AFNOR (Association Française de Normalisation). 1993. Qualité de l'eau Dosage des nitrites Méthode par spectrométrie d'absorption moléculaire. NF EN 26777. Association Française de Normalisation, Saint Denis, France.

AFNOR (Association Française de Normalisation). 2005. Qualité de l'eau Dosage du phosphore Méthode spectrométrique 
au molybdate d'ammonium. NF EN ISO 6878. Association Française de Normalisation, Saint Denis, France.

AFNOR (Association Française de Normalisation). 2009a. Qualité de l'eau Dosage des anions dissous par chromatographie des ions en phase liquide Partie $1:$ dosage du bromure, chlorure, fluorure, nitrate, nitrite, phosphate et sulfate. NF EN ISO 10304. Association Française de Normalisation, Saint Denis, France.

AFNOR (Association Française de Normalisation). 2009b. Qualité de l'eau Prélèvement des macro invertébrés aquatiques en rivières peu profondes. XP T 90 333. Association Française de Normalisation, Saint Denis, France.

AFNOR (Association Française de Normalisation). 2010a. Qualité de l'eau Dosage de l'ammonium Partie 2: méthode spectro photométrique au bleu d'indophénol. NF T90 015 2. Associa tion Française de Normalisation, Saint Denis, France.

AFNOR (Association Française de Normalisation). 2010b. Qualité écologique des milieux aquatiques. Qualité de l'eau. Traitement au laboratoire d'échantillons contenant des macro invertébrés de cours d'eau. XP T 90 388. Association Française de Normalisation, Saint Denis, France.

Archaimbault, V., P. Usseglio Polatera, J. Garric, J. G. Wasson, and M. Babut. 2010. Assessing pollution of toxic sediment in streams using bio ecological traits of benthic macroinverte brates. Freshwater Biology 55:1430 1446.

Archaimbault, V., P. Usseglio Polatera, and J. P. Vanden Bossche. 2005. Functional differences among benthic macroinvertebrate communities in reference streams of same order in a given biogeographic area. Hydrobiologia 551:171 182.

Armitage, P. D., D. Moss, J. F. Wright, and M. T. Furse. 1983. The performance of a new biological water quality score system based on macroinvertebrates over a wide range of unpolluted running water sites. Water Research 17:333 347.

Besley, C. H., and B. C. Chessman. 2008. Rapid biological as sessment charts the recovery of stream macroinvertebrate assemblages after sewage discharges cease. Ecological Indi cators 8:625 638.

Bonada, N., N. Prat, V. H. Resh, and B. Statzner. 2006. Develop ments in aquatic insect biomonitoring: a comparative analy sis of recent approaches. Annual Review of Entomology 51: 495523.

Boon, P. J. 1988. The impact of river regulation on invertebrate communities in the UK. Regulated Rivers: Research and Management 2:389 409.

Briers, R. A., H. M. Cariss, and J. H. R. Gee. 2002. Dispersal of adult stoneflies (Plecoptera) from upland streams draining catchments with contrasting land use. Archiv für Hydrobiol ogie 155:627 644.

Campbell, I. C. 1978. A biological investigation of an organically polluted urban stream in Victoria. Australian Journal of Ma rine and Freshwater Research 29:275 291.

Canobbio, S., V. Mezzanotte, U. Sanfilippo, and F. Benvenuto. 2009. Effect of multiple stressors on water quality and mac roinvertebrate assemblages in an effluent dominated stream. Water, Air, and Soil Pollution 198:359 371.

Carey, R. O., and K. W. Migliaccio. 2009. Contribution of wastewater treatment plant effluents to nutrient dynamics in aquatic systems: a review. Environmental Management 44:205 217.

Charvet, S., A. Kosmala, and B. Statzner. 1998. Biomonitoring through biological traits of benthic macroinvertebrates: per spectives for a general tool in stream management. Archiv für Hydrobiologie 142:415 432.

Charvet, S., B. Statzner, P. Usseglio Polatera, and B. Dumont. 2000. Traits of benthic macroinvertebrates in semi natural French streams: an initial application to biomonitoring in Europe. Freshwater Biology 43:277 296.

Chessel, D., A. B. Dufour, and J. Thioulouse. 2004. The ade4 package I: one table methods. R News 4:5 10.

Chevenet, F., S. Dolédec, and D. Chessel. 1994. A fuzzy coding approach for the analysis of long term ecological data. Freshwater Biology 31:295 309.

Collier, K. J., and B. J. Smith. 1998. Dispersal of adult caddisflies (Trichoptera) into forests alongside three New Zealand streams. Hydrobiologia 361:53 65.

Corine Land Cover. 2006. Online European database of land cover. European Environment Agency, Copenhagen, Den mark. (Available from: http://sd1878 2.sivit.org/)

Crawford, C. G., D. J. Wangsness, and J. D. Martin. 1992. Re covery of benthic invertebrate communities in the White River near Indianapolis, Indiana, USA, following implemen tation of advanced treatment of municipal wastewater. Archiv für Hydrobiologie 126:67 84 .

Daniel, M. H. B., A. A. Montebelo, M. C. Bernardes, J. P. H. B. Ometto, P. B. De Camargo, A. V. Krusche, M. V. Ballester, R. L. Victoria, and L. A. Martinelli. 2002. Effects of urban sewage on dissolved oxygen, dissolved inorganic and organic carbon, and electrical conductivity of small streams along a gradient of urbanization in the Piracicaba River Basin. Water, Air, and Soil Pollution 136:189 206.

Dolédec, S., and B. Statzner. 2008. Invertebrate traits for the biomonitoring of large European rivers: an assessment of spe cific types of human impact. Freshwater Biology 53:617 634 .

Dolédec, S., B. Statzner, and M. Bournaud. 1999. Species traits for future biomonitoring across ecoregions: patterns along a human impacted river. Freshwater Biology 42:737 758.

Downes, B. J., L. A. Barmuta, P. G. Fairweather, D. P. Faith, M. J. Keough, P. S. Lake, B. D. Mapstone, and G. P. Quinn. 2002. Monitoring ecological impacts: concepts and practice in flowing waters. Cambridge University Press, New York.

European Commission. 2000. Directive 2000/60/CE of the Euro pean Parliament of the Council of $23^{\text {rd }}$ October 2000 estab lishing a framework for community action in the field of water policy. Official Journal of European Community 327:1 72.

Floury, M., P. Usseglio Polatera, M. Ferréol, C. Delattre, and Y. Souchon. 2013. Global climate change in large European rivers: long term effects on macroinvertebrate communities and potential local confounding factors. Global Change Bi ology 19:1085 1099.

Gayraud, S., B. Statzner, P. Bady, A. Haybachp, F. Schöll, P. Usseglio Polatera, and M. Bacchi. 2003. Invertebrate traits for the biomonitoring of large European rivers: an initial assess ment of alternative metrics. Freshwater Biology 48:2045 2064.

Gower, A. M., and P. J. Buckland. 1978. Water quality and the occurrence of Chironomus riparius Meigen (Diptera: Chiron omidae) in stream receiving sewage effluent. Freshwater Biol ogy 8:153 164 .

Gücker, B., M. Brauns, and M. T. Pusch. 2006. Effects of wastewater treatment plant discharge on ecosystem struc ture and function of lowland streams. Journal of the North American Benthological Society 25:313 329. 
Hynes, H. B. N. 1960. The biology of polluted waters. Liverpool University Press, Liverpool, UK.

Kerans, B. L., and J. R. Karr. 1994. A Benthic Index of Biotic Integrity (B IBI) for rivers of the Tennessee Valley. Ecologi cal Applications 4:768 785.

Kondratieff, P. F., and G. M. Simmons. 1982. Nutrient retention and macroinvertebrate community structure in a small stream receiving sewage effluent. Archiv für Hydrobiologie 94:83 98.

Lecerf, A., P. Usseglio Polatera, J. Y. Charcosset, D. Lambrigot, B. Bracht, and E. Chauvet. 2006. Assessment of functional integrity of eutrophic streams using litter breakdown and benthic macroinvertebrates. Archiv für Hydrobiologie 165: 105126.

Lenat, D. R. 1993. A biotic index for the southeastern United States: derivation and list of tolerance values, with criteria for assigning water quality ratings. Journal of the North Ameri can Benthological Society 12:279 290.

MacLeod, C. K., N. A. Moltschaniwskyj, and C. M. Crawford. 2008. Ecological and functional changes associated with long term recovery from organic enrichment. Marine Ecology Pro gress Series 365:17 24.

Macneale, K. H., B. L. Peckarsky, and G. E. Likens. 2005. Stable isotopes identify dispersal patterns of stonefly populations living along stream corridors. Freshwater Biology 50:1117 1130.

Marzin, A., V. Archaimbault, J. Belliard, C. Chauvin, F. Delmas, and D. Pont. 2012. Ecological assessment of running waters: do macrophytes, macroinvertebrates, diatoms and fish show similar responses to human pressures? Ecological Indicators 23:56 65.

McGill, B. J., B. J. Enquist, E. Weiher, and M. Westoby. 2006. Rebuilding community ecology from functional traits. Trends in Ecology and Evolution 21:178 185.

Menezes, S., D. J. Baird, and A. M. V. M. Soares. 2010. Beyond taxonomy: a review of macroinvertebrate trait based commu nity descriptors as tools for freshwater biomonitoring. Journal of Applied Ecology 47:711 719.

Mladenov, N., K. Strzepek, and O. M. Serumola. 2005. Water quality assessment and modeling of an effluent dominated stream, the Notwane River, Botswana. Environmental Moni toring and Assessment 109:97 121.

Mondy, C. P., and P. Usseglio Polatera. 2013. Using conditional tree forests and life history traits to assess specific risks of stream degradation under multiple pressure scenario. Sci ence of the Total Environment 461/462:750 760.

Mondy, C. P., B. Villeneuve, V. Archaimbault, and P. Usseglio Polatera. 2012. A new macroinvertebrate based multimetric index (I2M2) to evaluate ecological quality of French wade able streams fulfilling the WFD demands: a taxonomical and trait approach. Ecological Indicators 18:452 467.

Negishi, J. N., M. Inoue, and M. Nunokawa. 2002. Effects of channelisation on stream habitat in relation to a spate and flow refugia for macroinvertebrates in northern Japan. Fresh water Biology 47:1515 1529 .

Oksanen, J., F. G. Blanchet, R. Kindt, P. Legendre, P. R. Minchin, R. B. O'Hara, G. L. Simpson, P. Solymos, M. H. H. Stevens, and H. Wagner. 2013. vegan: community ecology package. R package version 2.0 10. R Project for Statistical Computing, Vienna, Austria.
Ortiz, J. D., and M. À. Puig. 2007. Point source effects on den sity, biomass and diversity of benthic macroinvertebrates in a Mediterranean stream. River Research and Applications 23:155 170

Oudin, L. C., and D. Maupas. 2003. Système d'évaluation de la qualité de l'eau des cours d'eau (SEQ Eau). Ministère de l'Écologie et du Développement Durable Agences de l'Eau, Paris, France. (Available from: http://sierm.eaurmc.fr/eaux superficielles/fichiers telechargeables/grilles seq eau v2.pdf)

Paul, M. J., and J. L. Meyer. 2001. Streams in the urban landscape. Annual Reviews of Ecology and Systematics 32:333 365.

Pielou, E. C. 1966. The measurement of diversity in different types of biological collection. Journal of Theoretical Biology 13:131 144

Pinto, A. L., S. Varandas, A. M. Coimbra, J. Carrola, and A. Fontaínhas Fernandes. 2010. Mullet and gudgeon liver histopathology and macroinvertebrate indexes and metrics upstream and downstream from a wastewater treatment plant (Febros River Portugal). Environmental Monitoring and Assessment 169:569 585.

Pinto, P., J. Rosado, M. Morais, and I. Antunes. 2004. Assess ment methodology for southern siliceous basins in Portugal. Hydrobiologia 516:191 214.

Prenda, J., and A. Gallardo Mayenco. 1996. Self purification, temporal variability and the macroinvertebrate community in small lowland Mediterranean streams receiving crude do mestic sewage effluents. Archiv für Hydrobiologie 136:159 170.

Rabeni, C. F., S. P. Davies, and E. Gibbs. 1985. Benthic inverte brate response to pollution abatement: structural changes and functional implications. Water Resources Bulletin 21: 489497.

RMC Water Agency. 2000. Les rivières eutrophisées prioritaires du SDAGE : stratégies d'action. French Water Agency Rhône Méditerranée Corse, Lyon, France. (Available from: http://sierm .eaurmc.fr/sdage/documents/note tech 3.pdf)

Rueda, J., A. Camacho, F. Mezquita, R. Hernández, and J. R. Roca. 2002. Effect of episodic and regular sewage discharges on the water chemistry and macroinvertebrate fauna of a Mediterranean stream. Water, Air, and Soil Pollution 140: 425444.

Shannon, C. E., and W. Weaver. 1949. The mathematical theory of communication. University Illinois Press, Urbana, Illinois.

Shieh, S. H., B. C. Kondratieff, and J. V. Ward. 1999. Longitudinal changes in benthic organic matter and macroinvertebrates in a polluted Colorado plains stream. Hydrobiologia 411: 191209.

Sládeček, V. 1973. System of water quality from the biological point of view. Archiv für Hydrobiologie 7:1 218.

Southwood, T. R. E. 1977. Habitat, the templet for ecological strategies? Journal of Animal Ecology 46:337 365.

Southwood, T. R. E. 1988. Tactics, strategies and templets. Oikos 52:3 18

Spänhoff, B., R. Bischof, A. Böhme, S. Lorenz, K. Neumeister, A. Nöthlich, and K. Küsel. 2007. Assessing the impact of efflu ents from a modern wastewater treatment plant on breakdown of coarse particulate organic matter and benthic macro invertebrates in a lowland river. Water, Air, and Soil Pollution 180:119 129 . 
Statzner, B., P. Bady, S. Dolédec, and F. Schöll. 2005. Inverte brate traits for biomonitoring of large European rivers: an initial assessment of trait patterns in least impacted river reaches. Freshwater Biology 50:2136 2161.

Statzner, B., and L. A. Bêche. 2010. Can biological invertebrate traits resolve effects of multiple stressors on running water ecosystems? Freshwater Biology 55:80 119.

Tachet, H., P. Richoux, M. Bournaud, and P. Usseglio Polatera. 2010. Invertébrés d'eau douce. Systématique, biologie, écologie. CNRS Editions, Paris, France.

Tilman, D. 2001. Functional diversity. Pages 109120 in S. A. Levin (editor). Encyclopedia of Biodiversity. Volume 3. Aca demic Press, San Diego, California.

Townsend, C. R. 1989. The patch dynamics concept of stream community ecology. Journal of the North American Ben thological Society 8:36 50.

Townsend, C. R., S. Dolédec, and M. Scarsbrook. 1997. Species traits in relation to temporal and spatial heterogeneity in streams: a test of habitat templet theory. Freshwater Biology 37:367 387 .

Townsend, C. R., and A. G. Hildrew. 1994. Species traits in relation to a habitat templet for river systems. Freshwater Biology 31:265 275.

Townsend, C. R., S. S. Uhlmann, and C. D. Matthaei. 2008. Individual and combined responses of stream ecosystems to multiple stressors. Journal of Applied Ecology 45:1810 1819.

Usseglio Polatera, P., and J. N. Beisel. 2002. Longitudinal changes in macroinvertebrate assemblages in the Meuse River: anthropogenic effects versus natural change. River Research and Applications 18:197 211.
Usseglio Polatera, P., M. Bournaud, P. Richoux, and H. Tachet. 2000a. Biological and ecological traits of benthic freshwater macroinvertebrates: relationship and definition of groups with similar traits. Freshwater Biology 43:175 205.

Usseglio Polatera, P., M. Bournaud, P. Richoux, and H. Tachet. 2000b. Biomonitoring through biological traits of benthic macroinvertebrates: how to use species databases? Hydro biologia 422/423:173 181.

Usseglio Polatera, P., and H. Tachet. 1994. Theoretical habitat templets, species traits, and species richness: Plecoptera and Ephemeroptera in the Upper Rhône River and its floodplain. Freshwater Biology 31:357 376.

Violle, C., M. L. Navas, D. Vile, E. Kazakou, C. Fortunel, I. Hummel, and E. Garnier. 2007. Let the concept of trait be functional! Oikos 116:882 892.

Wasson, J. G., A. Chandesris, H. Pella, and L. Blanc. 2002. Les hydro écorégions de France métropolitaine: approche régionale de la typologie des eaux courantes et éléments pour la défini tion des peuplements de référence d'invertébrés. Cemagref, Lyon, France.

Whitehurst, I. T., and B. I. Lindsey. 1990. The impact of organic enrichment on the benthic macroinvertebrate communities of a lowland river. Water Research 24:625 630 .

Wooster, D. E., S. W. Miller, and S. J. DeBano. 2012. An exami nation of the impact of multiple disturbances on a river sys tem: taxonomic metrics versus biological traits. River Research and Applications 28:1630 1643.

Wyzga, B. 1996. Changes in the magnitude and transformation of flood waves subsequent to the channelization of the Raba River, Polish Carpathians. Earth Surface Processes and Land forms 21:749 763 . 